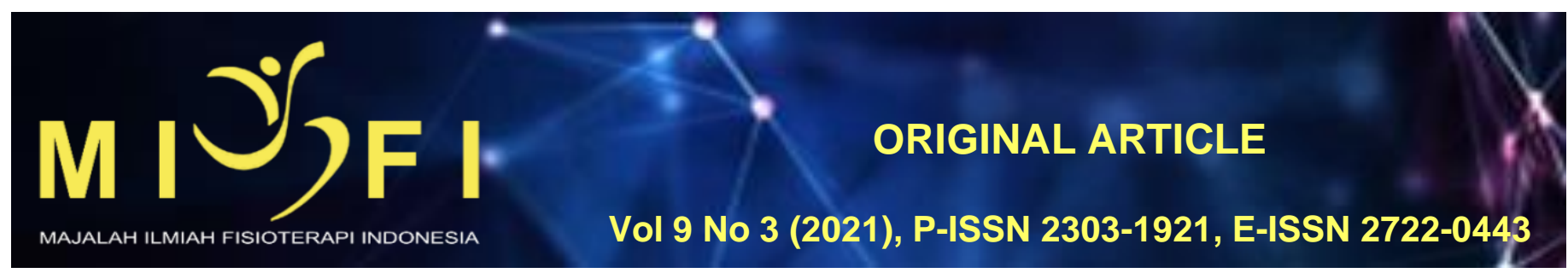

\title{
KELUHAN MUSCULOSKELETAL PADA PRAMUNIAGA YANG BEKERJA DI RAMAYANA DEPARTMENT
} STORE DENPASAR

\author{
Dessyta Luxsmadewi Aryadhe ${ }^{1}$, M. Widnyana ${ }^{2}$, Ni Wayan Tianing ${ }^{3}$, Ni Nyoman Ayu Dewi ${ }^{4}$ \\ ${ }^{1}$ Program Studi Sarjana Fisioterapi Dan Profesi Fisioterapi Fakultas Kedokteran Universitas Udayana, Denpasar, Bali \\ ${ }^{2}$ Departemen Fisioterapi, Fakultas Kedokteran Universitas Udayana, Denpasar, Bali \\ ${ }^{3,4}$ Departemen Biokimia, Fakultas Kedokteran Universitas Udayana, Denpasar, Bali \\ dessytaaryadhe@gmail.com
}

\begin{abstract}
ABSTRAK
Pramuniaga merupakan pekerja yang bertugas untuk mempromosikan suatu barang dan cenderung bekerja dalam posisi berdiri. Para pekerja mengeluhkan gangguan musculoskeletal sebagai risiko kesehatan yang sering terjadi. Tujuan penelitian ini adalah untuk mengetahui keluhan musculoskeletal dan tingkat risiko yang dialami pramuniaga yang bekerja di Ramayana Department Store Denpasar. Penelitian ini merupakn penelitian observasional dengan desain studi cross sectional. Penelitian dilakukan di Ramayana Department Store Denpasar pada bulan JuliAgustus 2019 dengan sampel yang berjumlah 58 orang. Teknik simple random sampling dijadikan sebagai teknik dalam mendapatkan sampel. Data awal didapatkan dari pengumpulan data yang dilakukan dengan melihat keluhan musculoskeletalmenggunakan kuesioner Nordic Body Map yang dinyatakan dalam skor. Dalam penelitian ini digunakan analisis univariat yaitu keluhan musculoskeletal dan tingkat risiko keluhan musculoskeletal. Karakteristik sampel pada penelitian ini umur 18-25 tahun 39 orang dan umur 26-30 tahun 19 orang. Keluhan yang dirasakan responden dengan skor 2 mayoritas pada kaki kiri $(43,1 \%)$, bahu kanan, betis kiri dan pergelangan kaki kanan $(41,4 \%)$, responden dengan skor 3 mengalami keluhan pada pinggang (27,6\%), punggung, betis kanan dan kaki kanan (25,9\%) dan responden dengan skor 4 mengalami keluhan pada punggung, betis kiri dan betis kanan (3,4\%). Proporsi responden yang memiliki keluhan musculoskeletal tingkat risiko rendah 39 orang, tingkat risiko sedang 18 orang dan tingkat risiko tinggi 1 orang. Responden mengalami keluhan pada daerah bahu, punggung, pinggang, betis, pergelangan kaki dan kaki. Keluhan musculoskeletal pada pramuniaga sebagian besar termasuk ke dalam tingkat risiko rendah.
\end{abstract}

Kata kunci: keluhan, musculoskletal, Nordic Body Map, pramuniaga

\section{MUSCULOSKELETAL COMPLAINTS ON HUMAN WORKING IN RAMAYANA DEPARTMENT STORE DENPASAR}

Salespeople are workers whose job is to promote an item and tend to work in a standing position. Workers complained of musculoskeletal disorders as a frequent health risk. The purpose of this study was to determine musculoskeletal complaints and the level of risk experienced by salespeople who work at Ramayana Department Store Denpasar. This research is an observational research with cross sectional study design. The study was conducted at the Ramayana Department Store Denpasar in July-August 2019 with a sample of 58 people. Simple random sampling technique used as a technique in getting samples. Preliminary data obtained from data collection is done by looking at musculoskeletal complaints using the Nordic Body Map questionnaire which is stated in the score. Characteristics of the sample in this study aged 18-25 years 39 people and aged 26-30 years 19 people. Complaints felt by respondents with a score of 2 majority on the left leg (43.1\%), right shoulder, left calf and right ankle (41.4\%), respondents with a score of 3 had complaints on the waist (27.6\%), back, right calf and right foot $(25.9 \%)$ and respondents with a score of 4 had complaints on the back, left calf and right calf (3.4\%). The proportion of respondents who have musculoskeletal complaints low risk level 39 people, moderate risk level 18 people and high-risk level 1 person. Respondents experienced complaints in the shoulder, back, waist, calf, ankle and foot area. Musculoskeletal complaints in salespeople are mostly included in the low risk level.

Keywords: complaints, musculoskeletal, Nordic Body Map, salespeople

\section{PENDAHULUAN}

Industri di Indonesia pada masa sekarang ini mengalami perkembangan yang semakin pesat. Hal ini dibuktikan dengan mal atau pusat perbelanjaan yang kian hari semakin berkembang, semakin populer dan kian mengalami persaingan. Perkembangan tersebut membuat jam buka supermarket menjadi lebih panjang dan tidak pernah sepi pengunjung. Supermarket yang dilengkapi oleh berbagai macam fasilitas harus memiliki banyak pekerja seperti pramuniaga untuk dapat melayani para pengunjung dengan baik. ${ }^{1}$

Risiko keluhan musculoskeletal seperti nyeri otot, kelelahan bahkan cidera biasanya ditimbulkan pada lingkungan kerja. Berdasarkan data Labor Force Survey dalam Health and Safety Excecutive (HSE) menyatakan bahwa di Negara Inggris tercatat sebanyak 507.000 pekerja mengalami keluhan musculoskeletal pada tahun 2016, dimana dari jumlah tersebut keluhan musculoskeletal yang dirasakan adalah pada ekstremitas bawah. ${ }^{2}$ Selain itu pada tahun 2005, Departemen Kesehatan melakukan studi mengenai masalah yang berkaitan dengan kesehatan di Indonesia. 
Studi tersebut mendapatkan hasil bahwa pekerja mengalami penyakit 40,5\% berkaitan dengan caranya bekerja. Studi tersebut dilaksanakan pada 12 kabupaten/kota yang ada di Indonesia, dimana meneliti 482 pekerja. Hasilnya adalah terdapat keluhan pada THT sebanyak 1,5\%, pada pernafasan sebanyak 3\%, pada saraf sebanyak $6 \%$, pada kardiovaskuler sebanyak $8 \%$ dan pada musculoskeletal sebanyak $18 \% .^{3}$

Dalam melakukan pekerjaan, pasti memiliki risiko baik risiko pada kesehatan maupun risiko dalam melakukan aktivitas kerja. ${ }^{4}$ Risiko tersebut kadang menimbulkan masalah yang biasanya seringkali tidak dihiraukan pada saat bekerja yang menyebabkan munculnya nyeri leher, nyeri tangan, nyeri punggung dan nyeri kaki yang disebut dengan keluhan musculoskeletal. ${ }^{5}$ Para pekerja mengeluhkan keluhan musculoskeletal sebagai risiko kesehatan yang sering terjadi. Keluhan yang dirasakan umumnya seperti pegal-pegal, nyeri, sakit dan lainnya pada sistem otot (musculoskeletal). ${ }^{6}$ Keluhan ini juga memiliki istilah lain yang sering digunakan seperti Musculoskeletal Disorder (MSD), Cumulative Trauma Disorders (CTD), Repetitive Strain Injuries (RSI) dan Repetitive Motion Injury (RMI). ${ }^{7}$

Keluhan musculoskeletal sering menyebabkan ketidaknyamanan saat bekerja yang dapat memicu stress atau ketidakpuasan dalam bekerja serta tidak mampu dalam menyelesaikan pekerjaan dengan baik dan berakhir pada penurunan produktivitas. ${ }^{8} \mathrm{Hal}$ tersebut dapat membuktikan bahwa keluhan musculoskeletal (MSD) merupakan masalah yang harus diperhatikan terutama dalam industri. ${ }^{9}$

Untuk menilai keluhan musculoskeletal dapat menggunakan kuesioner Nordic Body Map. Kuesioner ini terdiri dari 28 bagian otot-otot skeletal. Kuesioner ini dimanfaatkan untuk mengetahui dan mencari secara detail keluhan atau rasa sakit pada bagian tubuh ketika sedang bekerja. Penggunaan kuesioner telah memenuhi standar dan valid dalam penggunaannya walaupun kuesioner ini bersifat subjektif. ${ }^{10}$

Pramuniaga saat melakukan pekerjaannya, cenderung melakukannya dalam posisi berdiri karena harus melayani para pengunjung dan tidak menutup kemungkinan untuk berdiri sekitar 7 sampai 8 jam per harinya dan periode tersebut dapat dikatakan waktu yang cukup lama, sehingga memiliki risiko tinggi mengalami keluhan musculoskeletal. ${ }^{11}$ Dari hasil observasi yang dilakukan peneliti melalui wawancara langsung pada pramuniaga yang bekerja di Ramayana Department Store Denpasar terkait jam kerja dan keluhan yang dirasakan pada saat bekerja menyatakan bahwa pramuniaga yang bekerja di Ramayana Department Store Denpasar adalah 8 jam setiap shiftnya serta dalam waktu 8 jam tersebut dari 5 pramuniaga mengatakan bahwa terdapat keluhan musculoskeletal yang dirasakan seperti nyeri dan pegal-pegal pada area punggung serta kaki akibat dari lamanya berdiri saat bekerja.

Keluhan musculoskeletal dapat terjadi karena berdiri dengan waktu yang lama. Pada saat bekerja pramuniaga akan mengusahakan diri dalam menyeimbangkan tubuhnya dengan posisi berdiri. Keadaaan tersebut mengakibatkan otot-otot pada area punggung dan kaki menerima beban kerja statis. ${ }^{7}$ Pada kenyataannya 20 menit merupakan waktu yang dapat ditoleransi oleh tubuh untuk tetap berdiri dalam satu posisi. ${ }^{12}$ Jika lebih dari waktu tersebut dapat menyebabkan terjadinya peningkatan tekanan otot sehingga dapat menimbulkan rasa tidak nyaman pada bagian punggung bawah oleh karena berkurangnya elastisitas jaringan. Berdasarkan uraian di atas, peneliti tertarik untuk menggambarkan keluhan musculoskeletal pada pramuniaga yang bekerja di Ramayana Department Store Denpasar.

\section{METODE}

Penelitian ini telah disetujui Komisi Etik Fakultas Kedokteran Universitas Udayana dengan nomor 2055/UN14.2.2.VII.14/LP/2019. Penelitian ini termasuk dalam penelitian observasional yang memiliki desain studi cross sectional, dimana peneliti harus melakukan observasi pada satu periode atau waktu tertentu sehingga pada studi ini peneliti tidak perlu melakukan tindak lanjut dari apa yang telah diukur. ${ }^{13}$ Penelitian ini dilakukan di Ramayana Department Store di Denpasar pada bulan Juli-Agustus 2019 dengan meneliti seluruh pramuniaga yang bekerja di store tersebut. Dengan menentukan beberapa kriteria, maka didapatkan sampel yang berjumlah 58 responden. Teknik simple random sampling dijadikan sebagai teknik dalam mendapatkan sampel. Kuesioner Nordic Body Map dijadikan sebagai sarana untuk mengumpulkan data, dimana bertujuan untuk melihat keluhan musculoskeletal. Data kemudian dianalisis dengan analisis univariat yaitu keluhan musculoskeletal dan tingkat risiko keluhan musculoskeletal.

\section{HASIL}

Responden dalam penelitian ini adalah pramuniaga yang bekerja di Ramayana Department Store Denpasar. Sampel yang didapatkan berjumlah 58 orang yang telah memenuhi kriteria dan memberikan persetujuan sebagai responden. Dari segi usia, responden berkisar pada usia 18-30 tahun. Berikut adalah tabel analisis data penelitian.

Tabel 1. Distribusi Data Sampel Berdasarkan Usia Pada Pramuniaga

Karakteristik Responden Jumlah (orang) Proporsi (\%)

Usia (tahun)

18-25

67,2

26-30

19

32,8

Total

58

100

Tabel 1. menunjukkan deskripsi karakteristik sampel berdasarkan usia dengan kategori usia yang digunakan dalam penelitian ini yaitu masa remaja akhir $(18-25$ th) sebanyak 39 orang $(67,2 \%)$ dan masa dewasa awal $(26-30$ th) sebanyak 19 orang $(32,8 \%)$. 
Tabel 2. Distribusi Keluhan Muskuloskeletal

\begin{tabular}{llcccc}
\hline & & \multicolumn{4}{c}{ Proporsi (\%) } \\
\cline { 3 - 5 } & & 1 & 2 & 3 & 4 \\
\hline 0 & Sakit/kaku di leher bagian atas & 62,1 & 34,5 & 3,4 & 0 \\
1 & Sakit/kaku di leher bagian bawah & 60,3 & 34,5 & 5,2 & 0 \\
2 & Sakit di bahu kiri & 58,6 & 39,7 & 1,7 & 0 \\
3 & Sakit di bahu kanan & 55,2 & 41,4 & 3,4 & 0 \\
4 & Sakit pada lengan atas kiri & 70,7 & 29,3 & 0 & 0 \\
5 & Sakit pada punggung & 36,2 & 34,5 & 25,9 & 3,4 \\
6 & Sakit pada lengan atas kanan & 60,3 & 37,9 & 1,7 & 0 \\
7 & Sakit pada pinggang & 31 & 39,7 & 27,6 & 1,7 \\
8 & Sakit pada bokong & 55,2 & 32,8 & 10,3 & 1,7 \\
9 & Sakit pada pantat & 75,9 & 12,1 & 10,3 & 1,7 \\
10 & Sakit pada siku kiri & 70,7 & 27,6 & 1,7 & 0 \\
11 & Sakit pada siku kanan & 74,1 & 24,1 & 01.07 & 0 \\
12 & Sakit pada lengan bawah kiri & 74,1 & 25,9 & 0 & 0 \\
13 & Sakit pada lengan bawah kanan & 72,4 & 24,1 & 3,4 & 0 \\
14 & Sakit pada pergelangan tangan kiri & 70,7 & 27,6 & 1,7 & 0 \\
15 & Sakit pada pergelangan tangan kanan & 77,6 & 19 & 3,4 & 0 \\
16 & Sakit pada tangan kiri & 72,4 & 27,6 & 0 & 0 \\
17 & Sakit pada tangan kanan & 74,1 & 25,9 & 0 & 0 \\
18 & Sakit pada paha kiri & 56,9 & 31 & 12,1 & 0 \\
19 & Sakit pada paha kanan & 51,7 & 34,5 & 13,8 & 0 \\
20 & Sakit pada lutut kiri & 46,6 & 37,9 & 13,8 & 1,7 \\
21 & Sakit pada lutut kanan & 41,4 & 37,9 & 19 & 1,7 \\
22 & Sakit pada betis kiri & 32,8 & 41,4 & 22,4 & 3,4 \\
23 & Sakit pada betis kanan & 31 & 39,7 & 25,9 & 3,4 \\
24 & Sakit pada pergelangan kaki kiri & 39,7 & 37,9 & 22,4 & 0 \\
25 & Sakit pada pergelangan kaki kanan & 37.09 .00 & 41,4 & 20,7 & 0 \\
26 & Sakit pada kaki kiri & 36,2 & 43,1 & 20,7 & 0 \\
27 & Sakit pada kaki kanan & 37,9 & 36,2 & 25,9 & 0 \\
\hline
\end{tabular}

Tabel 2. menunjukan distribusi keluhan musculoskeletal responden. Responden dengan skor 2 (agak sakit) mayoritas mengalami keluhan pada bagian kaki kiri $(43,1 \%)$, bahu kanan, betis kiri dan pergelangan kaki kanan $(41,4 \%)$, sedangkan responden dengan skor 3 (sakit) mengalami keluhan pada bagian pinggang (27,6\%), punggung, betis kanan dan kaki kanan $(25,9 \%)$ dan untuk responden dengan skor 4 (sakit sekali) mengalami keluhan pada bagian punggung, betis kiri dan betis kanan $(3,4 \%)$.

Tabel 3. Gambaran Tingkat Risiko Keluhan Musculoskeletal

\begin{tabular}{lcc}
\hline Variabel & Frekuensi & Proporsi (\%) \\
\hline Tingkat Risiko & & \\
Rendah & 39 & 67,2 \\
Sedang & 18 & 31,0 \\
Tinggi & 1 & 1,7 \\
Sangat Tinggi & 0 & 0 \\
\hline Total & 58 & 100 \\
\hline
\end{tabular}

Tabel 3. menunjukan tingkat risiko keluhan musculoskeletal yang dialami oleh pramuniaga yang bekerja di Ramayana Department Store Denpasar. Pada Tabel 3, dapat dilihat proporsi yang mengalami keluhan musculoskeletal yaitu sebanyak 39 orang $(67,2 \%)$ dengan tingkat risiko rendah, 18 orang $(31,0 \%)$ dengan tingkat risiko sedang, 1 orang $(1,7 \%)$ dengan tingkat risiko tinggi dan tidak ada pramuniaga yang memiliki tingkat risiko sangat tinggi.

\section{DISKUSI}

\section{Karakteristik Responden}

Dari hasil penelitian ini, responden adalah pramuniaga yang bekerja di Ramayana Department Store Denpasar. Karakteristik sampel yang didapat berjumlah 58 orang laki-laki. Berdasarkan usia, responden berkisar antara 18-30 tahun. Pada penelitian ini jumlah usia 24 tahun paling banyak yaitu 10 orang. Keluhan musculoskeletal dipengaruhi oleh usia. Keluhan musculoskeletal cenderung terjadi pada usia 25-65 tahun dimana termasuk usia aktif dalam bekerja. Pada usia 35 tahun biasanya keluhan pertama mulai terjadi. Kekuatan dan juga ketahanan otot akan mulai mengalami proses penurunan seiring dengan berjalannya usia sehingga keluhan pada otot juga akan meningkat. ${ }^{14}$

Penelitian Mubarak dkk. menyatakan bahwa seseorang yang telah menginjak usia 20 tahun dapat merasakan keluhan musculoskeletal dan puncak keluhan tertinggi dijumpai pada usia seseorang yang menginjak 50 tahun. Usia tersebut sebenarnya masih dalam golongan usia yang produktif, namun bisa saja pekerjaan yang dilakukannya dapat memicu adanya keluhan musculoskeletal. ${ }^{15}$ Sedangkan, menurut Bridger dalam Zulfiqor, pertambahan usia akan membuat seseorang mengalami degenerasi pada tulang, biasanya terjadi pada usia 30 tahun meliputi rusaknya jaringan dan juga cairan yang berkurang, hal-hal tersebut akan mengakibatkan tulang dan otot mengalami penurunan stabilitas. ${ }^{3}$

Berdasarkan hasil dalam penelitian ini setelah dibandingkan dengan beberapa penelitian lain yaitu penelitian Tarwaka (2010), penelitian Mubarak (2009) dan penelitian Bridger dalam Zulfiqor (2010) mayoritas pekerja yang berusia 
di bawah 35 tahun seharusnya tidak mengeluhkan keluhan musculoskeletal atau mungkin mempunyai level risiko kecil mengalami keluhan musculoskeletal.,14,15 Namun, setelah dilakukan penilaian keluhan musculoskeletal terhadap pramuniaga yang bekerja di Ramayana Department Store Denpasar didapatkan hasil bahwa sebagian besar pramuniaga dengan usia <35 tahun mengalami keluhan musculoskeletal. Hal tersebut sesuai dengan penelitian NIOSH dalam Maijunidah yang menjelaskan bahwa tingkat nyeri punggung tertinggi dialami oleh laki-laki dengan kelompok umur 20-24 tahun dan perempuan dengan kelompok umur 30-34 tahun. ${ }^{16}$

\section{Keluhan Musculoskeletal Pada Pramuniaga yang Bekerja di Ramayana Department Store Denpasar}

Penelitian ini dilakukan pada pramuniaga yang bekerja dengan posisi berdiri selama \pm 8 jam, berdasarkan keluhan musculoskeletal dalam penelitian ini didapatkan hasil bahwa responden mayoritas mengalami keluhan pada daerah bahu, punggung, pinggang, betis, pergelangan kaki dan kaki. Hasil penelitian yang dilakukan pada 58 responden menyatakan bahwa responden dengan skor 2 (agak sakit) mengalami sakit pada bagian kaki kiri (43,1\%), bahu kanan, betis kiri dan pergelangan kaki kanan $(41,4 \%)$, responden dengan skor 3 (sakit) mengalami keluhan pada bagian pinggang $(27,6 \%)$, punggung, betis kanan dan kaki kanan $(25,9 \%)$ dan untuk responden dengan skor 4 (sakit sekali) mengalami keluhan pada bagian punggung, betis kiri dan betis kanan (3,4\%). Hasil ini menunjukkan bahwa bekerja dengan posisi berdiri dalam waktu yang lama dapat menimbulkan terjadinya keluhan musculoskeletal.

Hal ini didukung oleh penelitian sebelumnya yaitu oleh Nadrah dimana $100 \%$ pramuniaga mengalami tingkat keparahan sangat sakit pada betis, pergelangan kaki dan kaki, 90\% sangat sakit pada pinggang dan $86,67 \%$ sangat sakit pada punggung. ${ }^{17}$ Penelitian lain dari Santoso terhadap operator SPBU yang bekerja dengan posisi berdiri juga menyatakan keluhan musculoskeletal yang paling banyak dirasakan oleh pekerja yaitu sakit di bagian bahu kanan sebanyak $26,08 \%$, di bagian punggung sebanyak $21,74 \%$, di bagian betis kanan sebanyak $21,74 \%$ dan di bagian betis kiri sebanyak 21,74\%. ${ }^{18}$ Penelitian Kusmayanitha mendukung hasil penelitian ini dimana terdapat 5 bagian tubuh dengan keluhan musculoskeletal paling tinggi yaitu sebanyak $84,6 \%$ terjadi pada pinggang bawah, $61,5 \%$ pada bahu, 48,1\% pada lutut, 25,0\% pada pergelangan tangan serta $21,2 \%$ pada betis dan kaki. ${ }^{19}$ Menurut Utari, Kalsum \& Mahyuni, pada pekerja terjadi keluhan musculoskeletal seperti gangguan peredaran darah akibat menumpuknya sisa hasil dari proses metabolisme seperti asam laktat yang sulit untuk dibawa keluar, sehingga kadar oksigen dan juga glukosa berkurang dan akibatnya timbul rasa nyeri. ${ }^{20} \mathrm{Hal}$ ini didukung oleh penelitian yang menyatakan bahwa pekerja memiliki risiko mengalami nyeri kaki lebih tinggi ketika pekerja tersebut berdiri lebih dari 50\% waktu bekerjanya dibandingkan pekerja yang hanya berdiri sebentar ketika bekerja. ${ }^{21}$

\section{Gambaran Tingkat Risiko Keluhan Musculoskeletal Pada Pramuniaga yang Bekerja di Ramayana Department Store Denpasar}

Penelitian ini terdapat 4 tingkat risiko keluhan musculoskeletal berdasarkan total skor individu yaitu, skor 24-49 termasuk dalam kategori tingkat risiko rendah, skor 50-70 termasuk dalam tingkat risiko sedang, skor 71-91 termasuk dalam tingkat risiko tinggi dan skor 92-112 termasuk tingkat risiko sangat tinggi.

Hasil penelitian yang dilakukan kepada pramuniaga yang bekerja di Ramayana Department Store Denpasar menunjukkan bahwa proporsi responden yang mengalami keluhan musculoskeletal tingkat risiko rendah 39 orang $(67,2 \%)$, tingkat risiko sedang 18 orang $(31,0 \%)$ dan tingkat risiko tinggi 1 orang $(1,7 \%)$. Penelitian yang dilakukan oleh Anggrianti, dkk. mendukung hasil penelitian ini dimana ditemukan 11 orang pekerja $(78,6 \%)$ mengalami keluhan nyeri kaki ringan dengan postur kerja berdiri risiko sedang, sedangkan 7 orang pekerja $(63,6 \%)$ mengalami keluhan nyeri kaki berat dengan postur kerja berdiri risiko tinggi. ${ }^{22}$

Keluhan musculoskeletal dengan tingkat risiko rendah belum memerlukan tindakan perbaikan, sedangkan pada risiko sedang mungkin memerlukan tindakan perbaikan dan pada keluhan musculoskeletal dengan tingkat risiko tinggi diperlukan adanya tindakan perbaikan segera. Pramuniaga cenderung bekerja dengan posisi berdiri sehingga otot-otot pada anggota gerak bawah mengalami tekanan tanpa mendapat kesempatan untuk relaksasi dan menyebabkan rasa sakit. Menurut Sang, dkk. keluhan musculoskeletal dapat bersifat sementara maupun menetap tergantung dari lamanya otot tersebut mengalami pembebanan. ${ }^{23} \mathrm{Hal}$ ini sejalan dengan penelitian Guo dalam Maijunidah bahwa risiko keluhan musculoskeletal semakin besar apabila pekerja terpajan faktor risiko dalam waktu yang lama. ${ }^{16}$ Pekerjaan dalam posisi berdiri dengan waktu yang cukup lama dapat menimbulkan rasa tidak nyaman saat bekerja bahkan termasuk bahaya ergonomi. ${ }^{17}$ Penelitian lain yang dilakukan oleh Wicaksono menunjukkan bahwa risiko Nyeri Punggung Bawah (NPB) lebih tinggi dialami oleh kelompok responden dengan lama berdiri $>2$ jam $(86,67 \%)$ dibanding dengan kelompok responden dengan lama berdiri $<2$ jam (33,33\%). ${ }^{24}$ Hasil ini sebanding dengan penelitian Gatam yang menyatakan bahwa bekerja dengan posisi berdiri dalam waktu lama, sikap berdiri yang tidak sesuai serta aktivitas yang menggunakan pengerahan tenaga merupakan penyebab paling sering dari nyeri punggung. ${ }^{25}$

Patofisiologi terjadinya keluhan musculoskeletal ini dikarenakan penggunaan otot yang berlebihan dan gerakan berulang. Hal ini mengakibatkan terjadinya akumulasi asam laktat pada otot. ${ }^{26}$ Trauma pada sistem musculoskeletal disebabkan oleh kontraksi otot yang melampaui kemampuan otot tersebut. ${ }^{27}$ Tidak hanya pada otot, trauma tersebut juga terjadi pada struktur lainnya seperti sendi dan ligament. Berdiri pada satu tempat dalam posisi statis dapat menyebabkan kurangnya mobilisasi pada sendi kaki dan lutut, jika terus dibiarkan maka akan menyebabkan keluhan seperti nyeri pada bagian tersebut. Selain itu berdiri pada posisi statis juga menyebabkan otot kaki mengalami kelelahan sehingga dapat mengakibatkan adanya gangguan aliran pada darah yang menuju jantung dikarenakan oleh disfungsional pompa otot pada bagian kaki.19

Dari hasil penelitian ini ditemukan bahwa pramuniaga mempunyai risiko terkena keluhan musculoskeletal, meskipun tingkat keluhan lebih banyak pada risiko rendah. Hal ini terjadi karena pramuniaga cenderung mempunyai tubuh yang cukup prima dan juga memiliki jasmani yang baik, sehingga hal tersebut dapat meminimalisir terjadinya keluhan musculoskeletal. Selain itu hal tersebut juga disebabkan karena mereka sudah terbiasa bekerja dengan sikap 
berdiri dan mereka menganggap bahwa keluhan tersebut adalah sesuatu yang sering terjadi sehingga mereka tidak begitu merasakan keluhan musculoskeletal.

Berdasarkan hal ini meskipun lebih banyak pramuniaga dengan keluhan musculoskeletal risiko rendah, maka harus tetap ditindak lanjuti dengan melakukan perbaikan cara maupun posisi saat bekerja yang sesuai dengan prinsip ergonomi seperti meminimalkan posisi statis saat bekerja dan mengimbanginya dengan melakukan peregangan ketika bekerja, karena jika dibiarkan maka keluhan akan semakin parah dan dapat mengakibatkan kelainan morfologi dan fungsional otot rangka. ${ }^{28}$

\section{SIMPULAN}

Berdasarkan analisis penelitian mengenai keluhan musculoskeletal pada pramuniaga yang bekerja di Ramayana Department Store Denpasar, dapat disimpulkan bahwa keluhan musculoskeletal pada pramuniaga berdasarkan hasil dari kuesioner menunjukkan bahwa mayoritas dari responden mengeluhkan sakit pada daerah bahu, punggung, pinggang, betis, pergelangan kaki dan kaki serta proporsi responden yang memiliki keluhan musculoskeletal sebagian besar termasuk ke dalam tingkat risiko rendah.

\section{DAFTAR PUSTAKA}

1. Sari SM. Sejarah Evolusi Shopping Mall. Dimensi Interior. 2010;8(1):52-62.

2. Amaliyah M. Karakteristik Sepatu Dengan Keluhan Muskuloskeletal Pada Kaki Dan Pergelangan Kaki Sales Promotion Girl Golden Market Jember. (Skripsi). Fakultas Kesehatan Masyarakat Universitas Jember; 2018.

3. Zulfiqor MT. Faktor-Faktor Yang Berhubungan Dengan Keluhan Musculoskeletal Disorders Pada Welder Di Bagian Fabrikasi PT. Caterpillar Indonesia Tahun 2010. (Skripsi). Fakultas Kedokteran dan IImu Kesehatan Universitas Islam Negeri Syarif Hidayahtullah Jakarta; 2010.

4. Sari EN, Handayani L, Saufi A. Hubungan Antara Umur dan Masa Kerja dengan Keluhan Musculoskeletal Disorders (MSDs) pada Pekerja Laundry. Jurnal Kedokteran dan Kesehatan. 2017;13(2):183-94.

5. Putri DW dan Adiartha G. Perbaikan Stasiun Kerja Menurunkan Listrik Otot Dan Keluhan Muskuloskeletal Pada Pengrajin Ukir Kayu Di Desa Batuan Gianyar Bali. Fakultas Kedokteran Universitas Udayana, Denpasar; 2016.

6. Rahawarin MIU. Gambaran Keluhan Muskuloskeletal Pada Karyawan Swalayan Hypermart Makassar Periode 2008-2009. Fakultas Kedokteran Universitas Hasanuddin Makassar; 2011.

7. Nurjanah S. Hubungan Sikap Kerja Duduk Dengan Keluhan Muskuloskeletal Pada Pekerja Bagian Reaching PT. Delta Merlin Dunia Textile Kebakkramat Karanganyar. (Skripsi). Fakultas Kedokteran Universitas Sebelas Maret, Surakarta; 2012.

8. Tampubolon JS, Adiatmika IP. Keluhan muskuloskeletal pada pekerja laundry di Kecamatan Denpasar Selatan, Bali. E-Jurnal Medika Udayana. 2014;3(5):592-601.

9. Purba NP. Keluhan Musculoskeletal Disorders (Msds) Pada Sales Promotion Girl (SPG) Pengguna Sepatu Hak Tinggi di Suzuya Medan Plaza Pada Tahun 2015. Fakultas Kesehatan Masyarakat USU, Medan; 2015.

10. Santoso S, Yasra R, Purbasari A. Perancangan Metode Kerja Untuk Mengurangi Kelelahan Kerja Pada Aktivitas Mesin Bor Di Workshop Bubutpt. Cahaya Samudra Shipyard. Profisiensi. 2014;2(2):155-164.

11. Pratiwi GA, Winaya IMN, Primayanti DAI. Hubungan Antara Berdiri Lama Terhadap Terjadinya Kejadian Hallux Valgus Pada Pramuniaga. Jurnal Majalah IImiah Fisioterapi Indonesia. 2018;6(2):11-14.

12. Susanti N, Kuntowato D. Hubungan berdiri lama dengan keluhan nyeri punggung bawah miogenik pada pekerja kasir di Surakarta. Pena Medika Jurnal Kesehatan. 2015;5(1):60-70.

13. Sastroasmoro S dan Ismael S. Dasar-Dasar Metodologi Penelitian Klinis. Edisi 5. Jakarta: Sagung Seto; 2014.

14. Tarwaka. Ergonomi Industri Dasar-Dasar Pengetahuan Ergonomi dan Aplikasi di Tempat Kerja. Solo: Harapan Press; 2010.

15. Mubarak WI, Chayatin N, dan Santoso BA. Ilmu keperawatan komunitas konsep dan aplikasi. Jakarta: Salemba Medika; 2009.

16. Maijunidah E. Faktor-Faktor Yang Mempengaruhi Keluhan Muskuloskeletal Disorder (MDS) Pada Pekerja Assembling PT. X Bogor Tahun 2010. (Skripsi). Fakultas Kedokteran dan IImu Kesehatan UIN Syarif Hidayatullah, Jakarta; 2010.

17. Nadrah N. Pengaruh Perbaikan Posisi Berdiri Terhadap Keluhan Musculoskeletal Disorders (MSDs) Pada Pramuniaga Departement Store Kota RantauPrapat Tahun 2018. (Tesis). Fakultas Kesehatan Masyarakat Universitas Sumatera Utara, Medan; 2018.

18. Santoso, G. Otot Vertebralis (Trapezius, Rhomboidius, Latissimus Dorsi) Dan Otot Tibia-Fibula (Otot Tibialis, Otot Flexsor Longus) Operator SPBU Kerja Posisi Berdiri Terbebani. Jurnal Statistika. 2015;7:10-14.

19. Kusmayanitha PR. Studi Prevalensi Keluhan Muskuloskeletal Pada Pekerja Pabrik Bata Merah Di Desa Tulikup Gianyar. (Skripsi). Fakultas Kedokteran Universitas Udayana, Denpasar; 2016.

20. Utari FY, Kalsum., Mahyuni EL. Hubungan Sikap Kerja Dengan Keluhan Musculoskeletal Pada Penyortir Tembakau Di Gudang Sortasi Tembakau Kebun Klumpang SUTK PTPN II Tahun 2015. (E-jurnal). Departemen Keselamatan dan Kesehatan Kerja FKM USU; 2015.

21. Halim I, Omar AR, Saman AM, Othman I. A review on health effects associated with prolonged standing in the industrial workplaces. ljrras. 2011;8(1):14-21.

22. Anggrianti SM, Kurniawan B, Widjasena B. Hubungan Antara Postur Kerja Berdiri Dengan Keluhan Nyeri kaki Pada pekerja Aktivitas Mekanik Section welding di PT. X. Jurnal Kesehatan Masyarakat (e-Journal). 2017;5(5):369-77.

23. Sang A, Djajakusli R, Russeng S. Hubungan Risiko Postur Kerja dengan Keluhan Musculoskeletal Disorders (MSDs) pada Pemanen Kelapa Sawit di PT. Sinergi Perkebunan Nusantara. Jurnal Kesehatan Masyarakat. 
Bagian Kesehatan dan Keselamatan Kerja. Fakultas Kesehatan Masyarakat. Universitas Hasanuddin. Makassar. 2013;2(2):1-14.

24. Wicaksono B. Faktor Yang Berhubungan Dengan Gangguan Nyeri Punggung Bawah Pada Bidan Saat Menolong Proses Persalinan. (Skripsi). Fakultas Kesehatan Masyarakat Universitas Airlangga; 2012.

25. Gatam M. Deteksi Dini Penyakit Akibat Kerja. 2006.

26. Kuatariska D. Pengaruh Latihan Peregangan Terhadap Penurunan Keluhan Musculoskeletal Disorders Pada Pekerja Batik Di Sokaraja. (Skripsi). Fakultas Ilmu Kesehatan Universitas Muhammadiyah Purwokerto; 2018.

27. Suma'mur PK. Hygiene Perusahaan dan Keselamatan Kerja. Jakarta: Gunung Agung; 2009.

28. Iridiastadi H, MSIE PD, Yassierli PD. Ergonomi suatu pengantar. Bandung: PT. Remaja Rosdakarya; 2014. 